\title{
The Role of Globalization in Formation of Pedagogical Communication
}

\author{
Huseyn Mirzayev \\ Ministry of Education, Azerbaijan Republic
}

\begin{abstract}
The article is commonly about the impact of globalization on participants of pedagogical process in the condition of communication. The globalization leaves its tracks in separate spheres of the educational system as well as it impacts all spheres of modern life. The relation between a teacher and a student differs with its peculiarity in the contemporary life. A pupil or a student differs totally in classifying the information gained in his activity. A modern student demonstrates a special attitude to everyday events and gets an independent position. Such reality demands the teacher of the day to have a very high practice; the necessity of contemporary training in the process of training-education can be marked as the appearance of globalization. It occurs as a demand for globalization as well. All these items after being analyzed bring some conclusions.
\end{abstract}

Keywords: globalization, a model of contemporary pedagogical communication, training technology, relationship among teachers and students integration

\section{Introduction}

Tendency of a group of demands had an impact on relationship among teachers and students relevant to special features of the age at different periods of time. Relationship between teaching (teacher) and studying (pupil) has become important for other social stratum and even in other private spheres. If we have a look at different periods of history, we can notice a respectful attitude of students to the teachers, which can be considered a very remarkable situation. This tendency, which directed to the image of the teacher is still kept and saved in different nations of the world.

By the end of the XX century in Azerbaijan the existence of a special and different attitude to the personality of a teacher had been introduced in the thinking of the students, almost the society in some other form. They identified the teacher and introduced him "as an angel" [2, 14].

This tendency was exaggerated so much that the students were out of belief that a teacher can use bread of water as a human being. Some observations made by us shows that the reality stressed above can still be met in several places.

As a result of innovations appeared in the space of education of the century the interference of educational technology through the educational process impacted remarkable on the training and formation of a student as a particular personality as well. The regard to the globalization through the world began to differ especially. Independent thinking, free activity, offer orientation to the principles which the contemporary education aims,

Huseyn Mirzayev, chief advisor in the section dealing with Pilot Projects of the Department of Education in the Ministry of Education of Azerbaijan Republic, Ph.D. on philosophical Ph.D. program of the Institution of educational problems. 
brings to alteration of purposes and results and hence appear some new missions as well [3, 62].

The main condition for each government for being recognized in the world is the level of educational system. The refreshment of operations, the spheres of manufacturing, technological means, and measuring the quality of training system in the globalizing world is one of the noticeable important aspects [3,28].

For the outstanding Russian investigator Kapitsa, the education is the sphere of industry directed to the future.

As globalization adjusts the demands and wishes directed to the future all the problems in this direction, even the relationship between teacher-student must be relooked again and it is one of the important problems of the day.

The very impact of globalization to the communication between teacher-student implements different regards of the society which cause a new look at this personage.

In modern life the use of ICT (information communication technology) and getting more information from different sources by the students causes the priority over teachers and this provides the students to get more information and knowledge [1, 42].

The necessity and importance of using new training technology, the increase of demands especially among teenagers, young people, and the great use of those opportunities has created a strong base for students (children teenagers) to demonstrate the technological victory over the old generation.

The children using the contemporary technology ( $\mathrm{TV}$, mobile phones, etc.) gain the upper hand over their parents. The devices are being controlled from the distance, new mobile phone devices make the parents turn to their children for help and this displays the real demonstration of the created situation indeed. This reality displayed in the relation between teacher-student has been an unavoidable impact on the mutual teacher-student relationship. "The teacher knows more than everybody"-the slogan like this has lost its meaning and power. The adult (teachers parents) did not use to it, but it was the only way that showed the reality of the said $[5,36]$.

Why was it important to apply the new educational methods in the globalizing world? Because it had the level which could meet the requirement of the state, social and public order and had to master qualified education which is still the main demand of the world. It is impossible to reach the aim or the appointed target in this direction without methods. The globalization from its appearance was appointed as a passage from industrial structure to information society in many countries [4, 19].

It is obvious that without globalization the creation of internet, transmission through television and radio was not possible.

Y. A. Komenski resembled the teacher without knowledge to a lamp without light or a spring without water $[2,13]$.

In this case the teacher who feels ready to lead educational process must have a high level of knowledge round his profession. He must have a power to detect the real potency of the students and must use every chance to realize them. A modern teacher must not be satisfied only with relating to a student as an equal participant at the educational process. The teacher must not forget that a student has a special outlook, special state of mind, unsimilar fantasy, rich emotional world, a special regard on nature and people, at last capability. The Russian investigator Ushinski said: "if the pedagogics aims to bring up a comprehensive man, it must first study him comprehensively" [6,23]. He always advised the teachers to study their students' physical condition, inner-moral world at maximal range. In the book of M. V. Clarin Innovations in Global Pedagogics, you can come to conclusion what in the comparatively form of traditional education and analysis of new technological 
education changes the activity of a teacher and opens a new way to psycho-pedagogical development $[4,58]$. If a teacher applies to the contemporary new technology in teaching process, it means that he has made a basic or several changes in his thinking or attitude.

\section{Methods}

The application of new technological training at secondary schools creates out the importance of responsibility to meet the real requirements of the purposes and aspects of the contemporary life.

This attitude makes them investigate and study without stopping.

Teachers must relate the students relevant to modern orders and offers. The difficulty comes out when most of the teachers feel not ready for this. For their opinion students play a role of an object as a positive creature who listens and acts everything said by them. In this case the teacher is not able to be a student's friend and does not accept it. Thus level of the teachers' character and their outlook cannot accept the philosophy of innovations. In the globalizing world interactivity stands in the content of the education taught at secondary school. It is possible to create the relationship of subject-subject training the student during the proses of comprehension of information and passing through the character of regularity implementing the standards of classic training system while the lesson-training process at secondary school. In this case while gaining new knowledge a teacher becomes facilitator (guide), the student becomes an investigator who plays the role of an inventor. In this sphere of life attitude subject-subject is the main catch of knowledge which is to be adopted is full of information taken modern life, for example, news, innovation on stop development related with society or nature, changes that information had nothing to do with the student and turn into an extra load for a student. Hence the interest of the children in accepting new knowledge and skills becomes less and less. It makes unavoidable the negative impact upon the students' mind and the sphere of activity. A survey tested in one of the secondary schools made over some parameters to determine the level of the knowledge, activity and the interest to the lessons of the students gives us a base to express over our opinion. The students' attitude to the underlined points is reflected in the given grid.

Table 1

Students Are Indicators of Activity Settings

\begin{tabular}{|c|c|c|c|c|c|}
\hline $\mathrm{S} / \mathrm{S}$ & $\begin{array}{l}\text { The main parameter } \\
\text { while listening to } \\
\text { the lesson }\end{array}$ & $\begin{array}{l}\text { The points relevant to the } \\
\text { parameters }\end{array}$ & $\begin{array}{l}\text { The number of students } \\
\text { showing positive } \\
\text { attitude (showing by \%) }\end{array}$ & $\begin{array}{l}\text { The number of students } \\
\text { showing negative } \\
\text { attitude (showing by \%) }\end{array}$ & $\begin{array}{l}\text { The number of } \\
\text { students agreed to "the } \\
\text { teacher knows better" } \\
\text { (showing by \%) }\end{array}$ \\
\hline \multirow{3}{*}{1} & \multirow{3}{*}{$\begin{array}{l}\text { The dynamic of the } \\
\text { teacher's activity at } \\
\text { the lesson }\end{array}$} & $\begin{array}{l}\text { The teacher stands only in } \\
\text { one position at the lesson. }\end{array}$ & $10 \%$ & $75 \%$ & $15 \%$ \\
\hline & & $\begin{array}{l}\text { The teacher acts } \\
\text { dynamically relevant to } \\
\text { the process of the lesson. }\end{array}$ & $87 \%$ & $4 \%$ & $9 \%$ \\
\hline & & $\begin{array}{l}\text { The teacher rules the } \\
\text { lesson in sitting position. }\end{array}$ & $7 \%$ & $81 \%$ & $12 \%$ \\
\hline
\end{tabular}

According to the experimental survey the student of the day wants to see at the auditorium the teacher who makes a dialogue, creating a discussion, implements successfully training technology during the process of teaching. The teacher organizing the training process according to the students' wishes gives us information at what rate the teacher is ready for training $[5,68]$. 
To create environment for the students of the day which meets their interest is not so easy. If the teacher organizes the process of training, he is responsible for in advance, this process will be enjoyable and purpose oriental for him. Otherwise the teacher can get into trouble in front of the students. In this case the teacher in the position of globalization at the base of new demands given to the new training system must take into consideration the usefulness, the importance of the teaching material according to the relevant period of time and almost relate the given material with contemporary life and changes made in the society. Other the students are obliged to accept passively the information readily given to them. This causes to limit their freedom and independence. A student is not a participant of the training process who shows his attitude to the event, he is simply and object who acts his role during the training process.

\section{Results}

In many cases part of the people are not satisfied with the innovations brought to the educational system. Of course, it is natural that not everybody can accept the innovations as they are. Here the aspects based on conservativeness or old traditions, irreconcilability over the innovations plays an important role. A part of educators confirm that the innovations brought to the training-educational system are not good and they can cause the loss $[6,18]$.

Globalization formed in the contemporary society, the political, economic development of every country depends on strengthening rapidly, its scientific value, development of qualified values that the county masters depends on technology that is in action is new qualified educational system. Globalization of the society provides the development of mutual exchange of knowledge, the implementation ICT in educational system and gaining knowledge in various ways [4, 48]. This process fastens the revolutionary changes between teacher and a student who are the main elements of pedagogical process As a result, we can stress that globalization is a concept which is directed to the rights and against exchange of minds of the participants of the pedagogical process. If to appreciate these items objectively, we can note that globalization is directed to the formation of new relations among teachers and students, learning it from the contemporary point of view and supporting them greatly.

\section{Discussion}

A: Investigation of the impact of globalization upon the relations between educator-student.

B: The priority of the student in getting more information over their teachers.

C. The impact of contemporary training technology on the relations of educator-student and determining the level of globalization.

\section{References}

Abbasbayli, A. N. (2007). Contemporary international relations and globalization. Baki.

Aliyev, R. I. (2000). Personality and ethno-psychological bases of formation. Baki.

Azerbaijan national encyclopedia. (2002). Oldturkizm national self comprehension and geostrategy.

Bunyatova, F., \& Abdulla, B. (2000). An interactive technology in training and behavior. Baki.

Damirov, A. H., Mammadov, S. M., \& Ismayilov, S. N. (2007). New training technology and modern lesson. Baki.

Nazarov, A. M., \& Mammadov, R. I. (2008). Pedagogical mastering. Baki. 